\title{
乱流モデルを用いた正弦波面上の乱流の数值シミュレーション
}

\section{Numerical simulation of turbulent flow over a wavy wall using turbulent models}

\author{
○ 堀内学 (富山県大 - 学) 永田哲郎(富山県大 - 学) 正 石塚勝(富山県大) 正 中川慎二(富山県大)
}

\begin{abstract}
Manabu HORIUCHI, Tetsuro NAGATA, Masaru ISHIZUKA and Shinji NAKAGAWA
Toyama Prefectural University, Kurokawa 5180, Imizu, Toyama 939-0398, Japan
\end{abstract}

Key Words: Turbulent model, Low Reynolds k- $\varepsilon$ model, V2F model, Separation, Sinusoidal surface

\section{1. 緒言}

波面上の流れは風による波の発生, 砂漠の砂丘や川底での

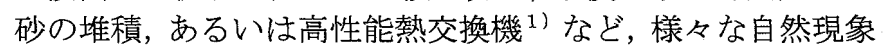
や工学的応用と関係しており, 多くの関心を集めている. 波 面上の流れははく離と再付着を伴う複雑な流れであり, 流れ が乱流である場合，正確な予測することは難しい.

乱流の直接数值シミュレーション (DNS) を用いることで, このような複雑な流れの予測が可能となった ${ }^{2)}$.しかし, DNS 計算の負荷は極めて大きく, 工学的に忘用することは難しい. 工学的問題に対して実用的な計算を行うためには, 乱流モデ ルの使用が必要不可欠である.

乱流モデルを用いた波面上乱流の数值シミュレーション

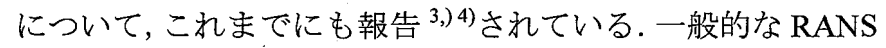
型乱流モデルでは, 波面上の乱流を正確に予測することは困 難である. そのため, 新たな乱流モデルの開発と評価が続け られている.

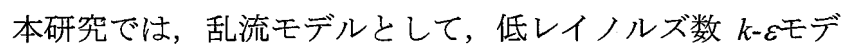

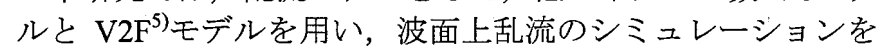
行った. 計算結果を DNS 結果と比較することでモデルの有 効性を検討した. V2F モデルは, 壁面に垂直な方向の速度変 動エネルギを考慮することで, 壁面近傍における非等方的な エネルギ輸送をモデル化する. そのため, はく離や再付着を 伴う流れに対して有効であるとされている.

\section{2. 計算方法}

Fig.1 に計算対象を示す.上面は平面壁, 下面は正弦波面 の壁で構成される 2 次元チャネルである. 流入面から主流方 向に座標 $x_{1}$, それに垂直に座標 $x_{2}$ をとる. 座標 $x_{2}$ の原点は 正弦波面最下部とする.P. Cherukat らによる DNS 結果 ${ }^{2)}$ と比 較するため, 彼らと同じ計算対象を採用し, 式 (1)で定義す るレイノルズ数 $R e$ を $R e=3460$ とした.

$$
R e=\frac{h U_{b} \rho}{2 \mu}
$$

ここで, 流路の高さ $h$, 波長 $\lambda$, 振幅 $a$, 波数はそれぞれ $5.00 \mathrm{~cm}$, $5.00 \mathrm{~cm}, 2.50 \mathrm{~mm}, 4$ である. 内部を流れる水の密度 $\rho$ と分子

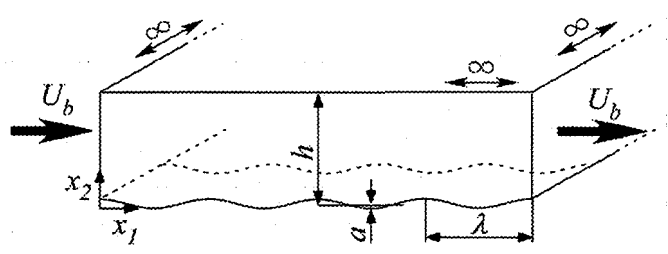

Fig.1 Simulation object
粘性係数 $\mu$ はそれぞれ $998 \mathrm{~kg} / \mathrm{m}^{3}, 8.89 \times 10^{-4} \mathrm{~kg} / \mathrm{ms}$ である.こ のとき, 断面平均流速 $U_{b}$ は $0.123 \mathrm{~m} / \mathrm{s}$ となる.

計算には, CDAJ社の「STAR-CD」を使用した. Navier-Stokes 方程式と連続の式を基礎方程式とし, 三次元有限体積法, SIMPLE 法で定常計算を行った. 対流項は一次精度風上差分, その他の項は二次精度中心差分で差分化する：格子は非スタ ッガードの構造格子を使用した. また楕円形格子生成法によ りスムージング処理を施し，格子の品質向上を行った.

境界条件として, 上部の平面と下部の正弦波面には滑りな しの壁面, 流入面および流出面には周期境界条件を与えた.

メッシュは $x_{1}$ 方向に $696, x_{2}$ 方向に 120 とし, 壁面に近い 領域は格子を集中させた. 事前にメッシュの大きさが結果に 与える影響について検討し，メッシュをこれより細かくして も結果に影響がないことを確認した。

\section{3. 計算結果と考察}

Fig.2 に波面一つ分の波面上無次元壁面せん断応力 $\tau_{w} / \rho U_{b}{ }^{2}$ を示す. $\tau_{w} / \rho U_{b}^{2}$ が正から負になる点ではく離, 負から正にな る点で再付着が生じている. Table.1にはく離点, 再付着点の

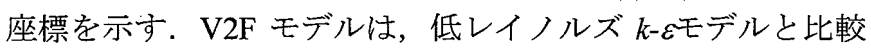
して, はく離点の予測精度が高く, 最大值も DNS に近い. 一方, V2F モデルでは, 再付着点が下流側に予測された.

主流方向速度 $U_{1}$ および壁面に垂直な方向の速度 $U_{2}$ を比較 するため, はく離点付近 $\left(x_{I} / \lambda=0.2\right)$ での無次元速度分布を Fig.3 に, 再付着点付近 $\left(x_{1} / \lambda=0.6\right)$ での分布を Fig.4 に示す. $\mathrm{V} 2 \mathrm{~F}$ モデルでは，壁面近傍をのぞく流路の大部分において，

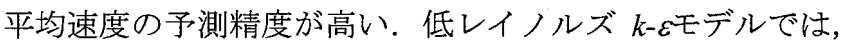
下面での壁面せん断応力を大きく予測するため, 主流方向速

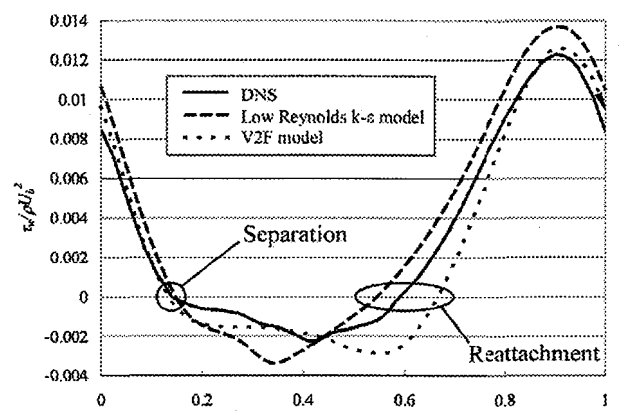

Fig.2 Shear stress at the wavy wall normalized by $\rho U_{b}^{2}$

Table.1 Separation and Reattachment point $\left(x_{1} / \lambda\right)$

\begin{tabular}{|l|c|c|}
\hline Case & Separation & Reattachment \\
\hline DNS & 0.140 & 0.590 \\
\hline Low Re k- $\varepsilon$ model & 0.147 & 0.547 \\
V2F model & 0.136 & 0.666 \\
\hline
\end{tabular}


度分布のピークが上面側に予測される，なお，V2F モデルで は再付着点をより下流に予測するため, $x_{1} / \lambda=0.6$ においては, 壁面近傍に生じる $U_{2}$ の極大值を予測できていない.

Fig.5 に波面近傍における $U_{2} / U_{b}$ の等高線を示す. 低レイノ ルズ数 $k-\varepsilon$ モデルでは, 負の速度の最大値が DNS より小さ く, その領域も小さい. V2F モデルでは, 負の速度の最大 值が下流側に現れる。しかし負の最大值は DNS より大きく

（絶対值は小さく）, 左側と真ん中側の二箇所に発生した.

Fig.6に波面近傍における無次元乱流エネルギ $k U_{b}^{2}$ の等高 線を示す. DNS は最大值がおよそ 0.050 であるが両モデル はおよそ 0.037 と小さかった。た最大值の予測位置も DNS よりも右にずれていた.

以上のことから, 今回用いたモデルでは, 波面からはく離 したせん断層部分において, 流れの予測精度が低いことが確 認された. 先に示した壁面せん断応力の相違も, これが大き な要因であると予想される. はく離せん断層や再付着点より 下流では, 非等方性がくずれ，スパン方向の乱れが増大する. この効果を取り入れた乱流モデルが必要であろう。今後, 波 面上での熱および物質移動を検討する際には，より精度の良 いモデルが必要である.

\section{4. 結言}

正弦波面上に発達する乱流の数值シミュレーションを, 低 レイノルズ数 $k-\varepsilon$ モデルとV2Fモデルを用いて行った. DNS 結果との比較から，V2F モデルを用いることで, 平均速度分 布の予測精度が向上することを明らかにした．ただし，壁面 近傍での予測精度は十分ではなく, 精度向上に向けた研究が 必要である。

\section{参考文献}

1）笠木ら,日本機械学会論文集, 70-698, B(2004), 2604-2611.
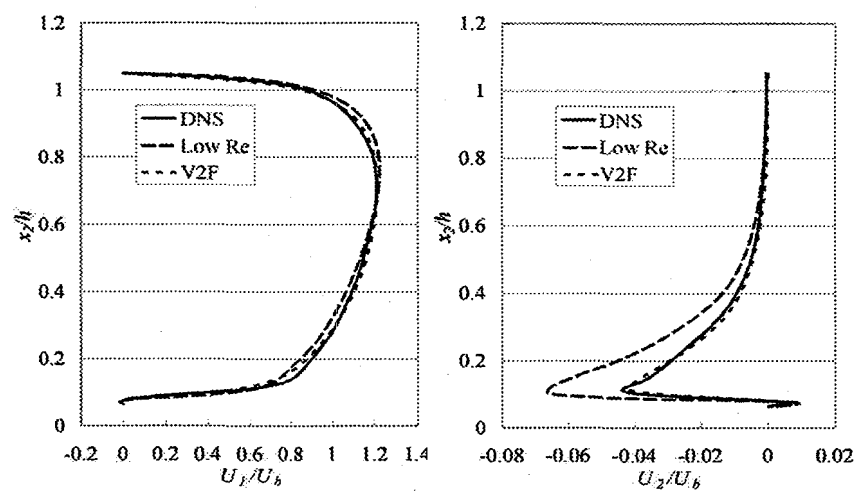

Fig.3 Profiles of $U_{1} / U_{b}$ and $U_{2} / U_{b}$ at $x_{1} / \lambda=0.2$
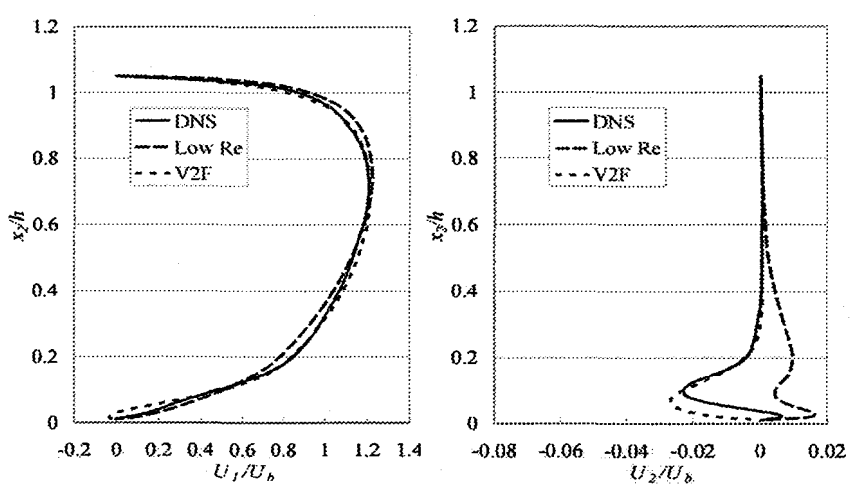

Fig.4 Profiles of $U_{1} / U_{b}$ and $U_{2} / U_{b}$ at $x_{1} / \lambda=0.6$
2) P.Cherukat, Y.Na, and T.J.Hanratty, Theoret. Compt. Fluid Dynamics (1998) 11:109-134.

3) T.S.Park, H.S.Choi, K.Suzuki, Int. J. Heat and Mass Transfer. 47: 2403-2415 (2004) .

4) VC Patel, IT Chon, JY Yoon, J. Fluids Eng. 113: 579-586, (1991).

5) S.Parneix, P.A.Durbin and M.Behnia, Flow Turbulent and Combustion 60: 19-46, (1998)
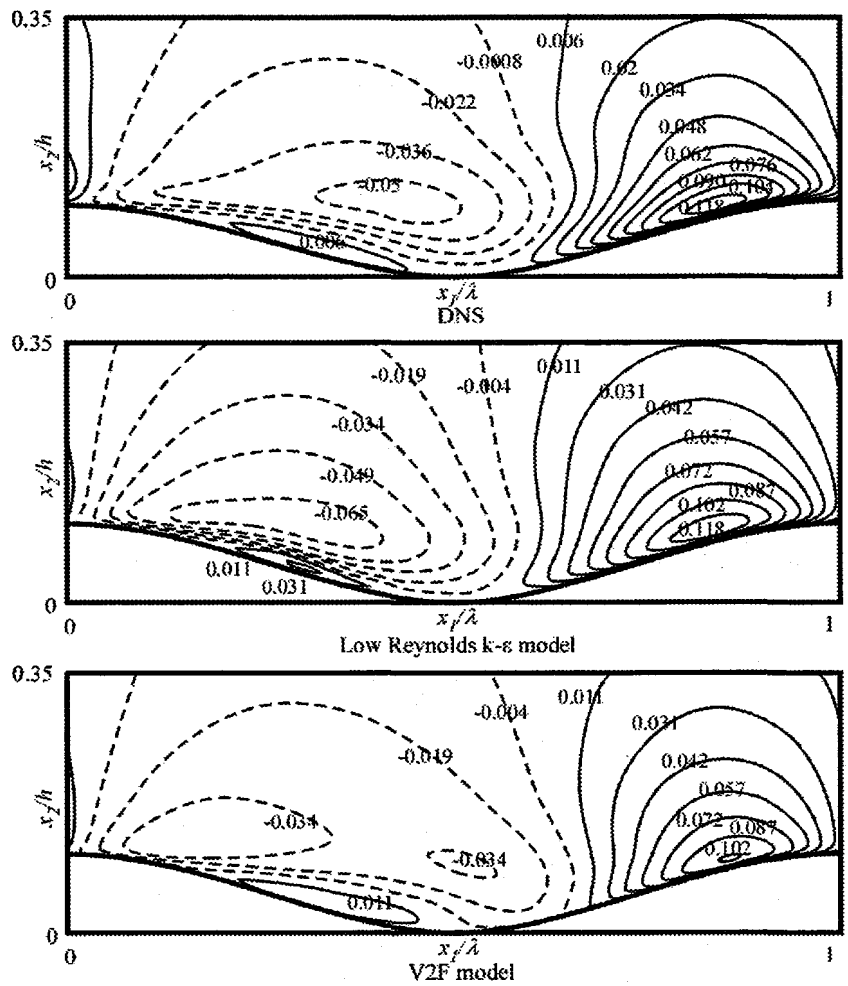

Fig. 5 Contours of $U_{2} / U_{b}$
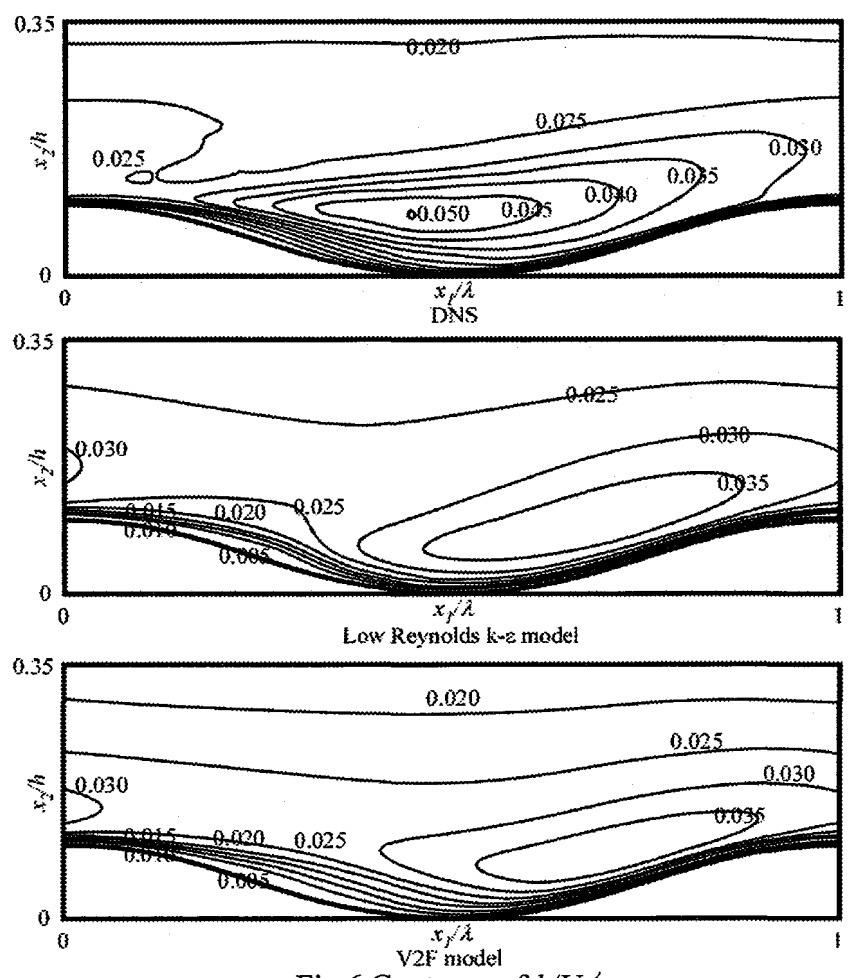

Fig. 6 Contours of $k / U_{b}^{2}$ 